\title{
Positive Education: Innovation in Educational Interventions Based on Positive Psychology*
}

\author{
Cecilia Cesa Schiavon ${ }^{1, * *}$ (D), Livia Padilha Teixeira ${ }^{1}$ (D), Léia Gonçalves Gurgel ${ }^{1}$ (D), \\ Cleidilene Ramos Magalhães ${ }^{1}$ (D), \& Caroline Tozzi Reppold ${ }^{1}$ (D) \\ ${ }^{1}$ Universidade Federal de Ciências da Saúde de Porto Alegre (UFCSPA), Porto Alegre, RS, Brasil
}

\begin{abstract}
School is configured as a social space that can essentially contribute to cognitive and emotional evolvement. Furthermore, it emerges as an important resource for Positive Psychology. This review aimed to evaluate studies that present interventions based on Positive Education. Databases searched were MEDLINE, LILACS, Psycinfo, SciELO, and Scopus, using the terms "Positive Education" and "Intervention". The study's analysis was descriptive, and the characteristics of the interventions were reported. Fourteen studies that met the proposed eligibility criteria were included. As a result, nine studies were focused on positive education in the children's and adolescents, three were directed to college students, and two exclusively meant for teachers and school leaders. The importance of stimulating the development of strength of character among students were apparent.
\end{abstract}

KEYWORDS: Education, Positive Psychology, Intervention, Educational Psychology

\section{Educação Positiva: Inovação em Intervenções Educacionais Baseadas na Psicologia Positiva}

\begin{abstract}
RESUMO - A escola é um ambiente social que essencialmente pode contribuir para o desenvolvimento cognitivo e emocional dos sujeitos, surgindo como um importante recurso da Psicologia Positiva. A presente revisão objetivou avaliar estudos que apresentam intervenções baseadas em Eduação Positiva. As bases acessadas foram MEDLINE, LILACS, Psycinfo, SciELO e Scopus, por meio dos termos "Positive Education" e "Intervention". Os estudos foram analisados de forma descritiva e as características das intervenções foram descritas. Quatorze estudos satisfizeram os critérios de inclusão desta revisão. Como resultado, 9 estudos focalizaram a eduação positiva de crianças e adolescentes, 3 foram direcionados para estudantes universitários e 2 consideraram exclusivamente professores e líderes escolares. Evidenciou-se a importância de estimular o desenvolvimento da força de caráter entre os alunos.
\end{abstract}

PALAVRAS-CHAVE: Educação, Psicologia Positiva, Intervenção, Psicologia Educacional

The twenty-first-century educational landscape has been facing numerous factors not hitherto present, such as social changes, natural disasters, terrorism, poverty, and the increasing incidence of psychological disorders in children and adolescents (Waters, 2013), and these may act as obstacles to the students' learning process. This issue is a concern for educational institutions, especially as school is configured as the social space that can substantially contribute to cognitive, social, and emotional development of young people. In this scenario, innovative strategies in education are required to enhance and support students and teacher's well-being, as well as the school institution as a collective space. Meanwhile, Positive Education emerges as an important resource developed by Positive Psychology, and is considered a branch of this new area of psychology (Green, Oades, \& Robinson, 2011). Specifically, it is an approach that promotes not only academic skills, but also skills for the increase or development of well-being,

\footnotetext{
* Support: Capes, $\mathrm{CNPq}$

** E-mail: cecilia.cesa@gmail.com

- Submetido: 03/03/2017; Revisado: 12/09/2017; Aceito: 24/02/2018.
} 
happiness and positive emotions - which are advocated by the authors as promoting learning and academic success (Seligman, Ernst, Gillham, Reivich, \&Linkins, 2009).

According to a chronological perspective on the development of Positive Education in the scientific field, it emphasizes that Positive Education has its origins formalized from the criticism made by Seligman et al. (2009), of the traditional education model, comparing what parents wanted for their children and what schools taught. To this end, the authors conducted a study in which two lists prepared by parents were generated. The first contained more generic and comprehensive desires, such as happiness, balance, goodness, and satisfaction. In the second, attributes related to the expectation as to what the schools teach, as a discipline, literacy, compliance and success, were mentioned. The authors noted that the first list was composed of aspects related to Positive Psychology, more specifically to well-being, and the second of questions related to education, with no overlap between the two lists.

Also in 2009, Seligman and colleagues addressed the issue of education, in an article entitled "Positive education: Positive psychology and classroom interventions", defining Positive Education as the education for traditional knowledge and happiness, speculating that Positive Education could form the basis of a "new era of prosperity," a policy that values wealth and well-being. In the publication, they discussed the high global prevalence of depression among young people, the small increase in life satisfaction, the synergy between learning and positive emotion, and the fact that the skills for happiness could be taught in school (Seligman et al., 2009). In the same year, Snyder and Lopez (2009) also defended the use of attributes of Positive Psychology in education, citing some practical examples. Later, Seligman (2011) pointed out that well-being should be taught in schools and described positive educational experiences.

Since then, there has been an increase in studies in the field, and initiatives point to this fact, such as the "Positive Education Schools Association" that encourages and shares schools' experiences in this area. So, considering the growth of research in Positive Psychology, and its applicability in education, this review aimed to evaluate studies which present interventions in this context, based on the concept of Positive Education. For this purpose, interventions were considered as those actions included in the definition of Syn \& Lyubomirsky (2009), which encompasses programs, training, practice, treatment methods, or activities whose aim is to cultivate emotions, positive behavior, and cognition.

\section{METHOD}

\section{Research Strategy}

The following electronic databases were searched up to November 25, 2015: MEDLINE (accessed through PubMed), LILACS, Psycinfo, SciELO, and Scopus. The search terms used were "Positive Education" and "Intervention". Words related to the outcomes of interest were not included in order to increase the sensitivity of this research. All those studies that dealt with interventions in the context of Positive Education were included. As exclusion criteria, we considered studies that had, as their purpose, psychoeducation only, not presenting an intervention based on Positive Education and/or related attributes or which were not articles, in addition to studies conducted outside the educational context (such as the clinical and hospital contexts).

\section{Data Analysis}

The titles and abstracts of all articles identified by the search strategy were assessed by the investigators. The abstracts that did not provide sufficient information regarding eligibility criteria were selected for evaluation of the full text. Two reviewers independently assessed the full articles and made their selections in accordance with the eligibility criteria. Subsequently, data collection was conducted regarding methodological characteristics, interventions, and outcomes of the studies using standardized forms. Disagreements, in all phases of the study, were resolved by consensus among researchers.

The analysis of the studies and the results were descriptive, and the main characteristics of interventions were reported. The quality of studies with a randomized design was analyzed based on the GRADE approach in order to highlight the strong and weak methodological points of the study. 


\section{RESULTS}

The initial search identified 185 articles. Of these, 162, which presented divergent themes from the objective of the study were excluded. Therefore, 14 studies that presented interventions in positive education and met the proposed eligibility criteria for this study were included. Figure 1 shows the flowchart of the selection of studies included in this review.

All studies included were published in international journals in English or Spanish. The journals' impact factor ranged from 0.69 to 2.987 , although there were also journals that had no impact factor found, which is probably due to the absence of an evaluation of this aspect. Table 1 shows the main characteristics of the studies included in this review, such as authors and year of publication, journal and impact factor, sample characteristics, applied intervention, intervention objectives and main results found.
185 Potentially relevant citation/quotes identified fro $\mathrm{m}$ all databases

86 Studies excluded for being literature reviews

76 Studies excluded on the basis of othe r eligibility criteria.

9 Could not be accessed in full.

14 Eligible studies

Figure 1. Flowchart of the studies selection

Table 1

Characteristics of the studies included in this review

\begin{tabular}{|c|c|c|c|c|}
\hline $\begin{array}{l}\text { Authors } \\
\text { (year) }\end{array}$ & $\begin{array}{c}\text { Country of } \\
\text { Origin }\end{array}$ & Periodical and IF & Sample & Intervention Used \\
\hline Aldenmyr (2012) & Sweden & $\begin{array}{c}\text { Journal of Moral } \\
\text { Education; } \mathrm{IF}=0.69\end{array}$ & $\begin{array}{l}\text { Four secondary education } \\
\text { teachers }\end{array}$ & "Life competence education (LCE)" \\
\hline $\begin{array}{l}\text { Baum et } \\
\text { al. (2014) }\end{array}$ & USA & $\begin{array}{l}\text { Gifted Child Quarterly; } \\
\qquad \mathrm{IF}=0.75\end{array}$ & $\begin{array}{l}\text { Ten students of } 11 \text { to } 13 \text { years } \\
\text { old, with high intellectual skills } \\
\text { and learning disorders. }\end{array}$ & Process model with multi perspectives \\
\hline $\begin{array}{l}\text { Niehues } \\
\text { et al. } \\
(2013)\end{array}$ & Australia & $\begin{array}{l}\text { Journal of Adventure } \\
\text { Education and Outdoor } \\
\text { Learning; IF }=\text { not included }\end{array}$ & $\begin{array}{l}\text { Elementary school students, } \\
\text { parents and educators. }\end{array}$ & Playing games outdoors. \\
\hline $\begin{array}{l}\text { Rhodes \& Spiers } \\
\text { (2013) }\end{array}$ & Australia & $\begin{array}{l}\text { International Journal of } \\
\mathrm{IF}=\text { not included }\end{array}$ & $\begin{array}{l}\text { Australian girls aged between } 7 \\
\text { and } 12 \text { years. }\end{array}$ & $\begin{array}{c}\text { Restorative justice and exercises in student } \\
\text { leadership. }\end{array}$ \\
\hline $\begin{array}{l}\text { Bridges et al. } \\
\text { (2012) }\end{array}$ & USA & $\begin{array}{l}\text { Psychology Learning and } \\
\text { Teaching; IF = not included }\end{array}$ & $\begin{array}{l}\text { Psychology students enrolled } \\
\text { in the Positive Psychology } \\
\text { module/discipline. }\end{array}$ & $\begin{array}{l}\text { Student blogs based on the interventions: } \\
\text { "Three Good things", Signature Strengths" and } \\
\text { "Gratitude Letter". }\end{array}$ \\
\hline $\begin{array}{l}\text { Place\&Talen } \\
(2013)\end{array}$ & USA & $\begin{array}{l}\text { International Journal of } \\
\text { Psychiatry in Medicine; } \\
\qquad \mathrm{IF}=1.15\end{array}$ & 126 medical residency students. & $\begin{array}{c}\text { Intervention based on } 4 \text { main components: } \\
\text { concrete resources, positive chats, control and } \\
\text { curriculum. }\end{array}$ \\
\hline $\begin{array}{l}\text { Proctor et al. } \\
(2011)\end{array}$ & England & $\begin{array}{l}\text { Journal of Positive } \\
\text { Psychology; } I F=1.67\end{array}$ & $\begin{array}{l}319 \text { students in the second year } \\
\text { of elementary school. }\end{array}$ & Strengths Gym Program \\
\hline $\begin{array}{l}\text { Madden et al. } \\
\text { (2011) }\end{array}$ & Australia & $\begin{array}{l}\text { International Coaching } \\
\text { Psychology Review; IF= } \\
\text { not included }\end{array}$ & $\begin{array}{c}38 \text { boys (average age of } 10 \\
\text { years old). }\end{array}$ & $\begin{array}{l}\text { Based on boys' hope and engagement } \\
\text { attributes. }\end{array}$ \\
\hline $\begin{array}{l}\text { Duan et al. } \\
\text { (2014) }\end{array}$ & China & $\begin{array}{l}\text { J Happiness Stud; } \\
\text { IF }=1.683\end{array}$ & 285 Chinese. & Based on strength training \\
\hline $\begin{array}{l}\text { Tomyn } \\
(2015)\end{array}$ & Australia & Soc Indic Res; IF=1.4 & 4243 participants & $\begin{array}{l}\text { Intervention based onthe "Subjective } \\
\text { Wellbeing Homeostasis Theory". }\end{array}$ \\
\hline $\begin{array}{l}\text { Shoshani e } \\
\text { Steinmetz (2014) }\end{array}$ & Israel & $\begin{array}{l}\text { J Happiness Stud; } \\
\text { IF=1.683 }\end{array}$ & $\begin{array}{l}537 \text { seventh and ninth grade } \\
\text { students. }\end{array}$ & Intervention based on school psychology. \\
\hline $\begin{array}{l}\text { Leventhal et al. } \\
\text { (2015) }\end{array}$ & India & $\begin{array}{l}\text { Journal of Adolescence; } \\
\text { IF = not included. }\end{array}$ & $\begin{array}{l}2308 \text { female students from } \\
\text { seventh and eighth grades. }\end{array}$ & Intervention program based on resilience. \\
\hline $\begin{array}{l}\text { White \& Waters } \\
\text { (2015) }\end{array}$ & Australia & $\begin{array}{c}\text { Journal of Positive } \\
\text { Psychology; IF= } 2.987\end{array}$ & $\begin{array}{l}\text { Eighth and eleventh grades } \\
\text { students ("K-12 school"). }\end{array}$ & $\begin{array}{l}\text { Initiatives from Peterson's postulates/tenets/ } \\
\text { principles about strength of character in the } \\
\text { school context. }\end{array}$ \\
\hline $\begin{array}{l}\text { Waters \& Stokes } \\
(2015)\end{array}$ & Australia & $\begin{array}{l}\text { The Australian Educational } \\
\text { and Developmental } \\
\text { Psychologist; IF }=0.0\end{array}$ & 27 school leaders & Program aimed towards gratitude. \\
\hline
\end{tabular}


With regard to interventions, it was observed that of the 14 articles included, nine were on the study of positive education in children's and adolescent's school context (Tomyn et al., 2015; Leventhal et al., 2015; Shoshani \& Steinmetz, 2014; Baum et al., 2014; Niehues et al., 2013; Rhodes \& Spiers, 2013; Proctor et al., 2011; Madden et al., 2011; White \& Waters, 2015), including, sometimes, the emphasis on parents, caregivers, as in the study of Niehues et al. (2013).

Three were directed at college students (Bridges et al., 2012; Place and Talen, 2013; Duan et al., 2014), only two exclusively meant for teachers (Aldenmyr et al., 2012.) and school leaders (Waters \& Stokes, 2015). In relation to the outlines, it was observed that five were case studies (Aldenmyr, 2012; Baum et al., 2014; Rhodes \& Spiers, 2013; White \& Waters, 2015; Waters \& Stokes, 2015), three presented other qualitative outlines (Bridges et al., 2012; Niehues et al., 2013; Place \& Talen, 2013), three with quasiexperimental outline (Duan et al., 2014; Proctor et al.; 2011,
Tomyn et al., 2015), two studies presented randomization (Leventhal, 2015; Madden et al., 2011) and a longitudinal study (Shoshani \& Steinmetz, 2014).

Regarding quality analysis, this was undertaken only in the studies by Madden et al. (2011) and Leventhal et al. (2015), as they were randomized clinically controlled, based on the GRADE approach recommended by the Cochrane Collaboration (Guyatt et al., 2008). This aims to measure the quality of the evidence found. It was observed that the study by Madden et al. (2011), despite the randomization description, presents inadequacy in aspects of baseline comparison, the description of losses and exclusions, and the allocation's blinding and confidentiality.

For the study of Leventhal et al. (2015), a fair presentation of randomization and baseline comparability, lack of description of blinding, and adequacy in the presentation of losses and exclusions were observed. The two studies presented low to moderate evidence quality.

\section{DISCUSSION}

From this review it was observed that the articles which exposed interventions based on the precepts of Positive Education were based on the studies of Seligman on the subject, demonstrating their application in different contexts and specific groups such as schoolchildren, students in higher education, parents, caregivers, teachers, and school leaders. Among the 14 studies that met the inclusion criteria, nine had schoolchildren as subjects.

In the first study, boys aged 10 and 11 years participated in the pilot study of Madden et al. (2011), which followed a coaching program as part of personal development and health plan in a private elementary school in Australia. Participants were selected by the school psychologist using the Beck.

Youth Inventory (Beck et al., 2005) and received eight training sessions over two school periods. The activities highlighted the strength of character, so the students were trained to identify personally significant goals, persistence on their goals, and new ways to utilize their strong points. Students also developed the "Future Charter," in which they described themselves at their best. There was a significant increase in self-reported measures of hope $(\mathrm{t}(37)=3.39$, $\mathrm{p}=<0.01)$ and engagement $(\mathrm{t}(37)=3.30, \mathrm{p}=<0.001)$. The study authors cite Seligman et al. (2009) as defining engagement as one of the three major pillars of happiness: life with engagement, meaningful life, and pleasant life. With regard to strengths, evaluated qualitatively, students rated each strength as their greatest strength in the following order of frequency: vitality, creativity, love, teamwork, love of learning and perseverance, humor, curiosity, leadership, bravery, gratitude and kindness (Madden et al., 2011).

In a qualitative study, Niehues et al. (2013) also described an intervention in children, but seeking to reach parents, educators and community volunteers from 9 Catholic schools, resulting in a total of 150 individuals. The children had their social behaviors monitored as part of a program called "Sydney Playground Project" (SPP). With an outdoor game, we tried to change parents' perceptions of risk, justified by the fact that risk can be positive and important in the development of children. Outdoor activities were designed to involve adults playing and guiding towards the health risks of a game outdoors for children. Participants had the opportunity to experience and challenge their automatic perceptions of risk, to reflect and tell stories about the experiences of their own family as a means to reframe their perceptions of risk. The results suggested that educators and parents benefited from this opportunity, therefore seeking to achieve common goals for children: health, happiness, and resilience (Niehues et al., 2013.).

The study by White and Waters reported an applied case study about two aspects of Peterson's contributions to school interventions based on Positive Education. The interventions focused on the aspects of "enabling institutions" and "applications of character strengths". For the study, five character strengths initiatives were applied in different contexts: English literature, strengths-based approach in sports, leadership positions, student counseling, and Positive Education in the curriculum. The results showed that the application of these initiatives is a process of continuous work which involves the whole school-teacher, students, and staff. Therefore, it was already observed that the implemented interventions had been understood and employed by them.

Interventions with children who needed a special approach were also found in this review (Baum et al., 2014; Rhodes \& Spiers, 2013). Rhodes and Spiers (2013), 
given the disparity between social, political, and economic aspects of indigenous Australians and non-indigenous, they evaluated the educational involvement of children from indigenous communities in a school. This school used a culturally appropriate example of organizational change to create an educational model that promotes social equity and equal opportunities. Through changes in school structure, which generated strong resistance from teachers at first, a difference in the support provided to indigenous students compared to other students was identified. Positive effects have occurred since the change was implemented, and indigenous and non-indigenous students, members of the same community working toward a common mission, began to develop relationships.

Also, with respect to children who need a special approach, Baum et al. (2014) presented a study with 10 children defined as "twice-exceptional (2e)", a term that refers to intellectually gifted children who have a disability (Beckley, 2012). Using a case study blueprint, the researchers analyzed data collected from students and teachers, parents' focus groups, school records, and psychological reports. The goal was to understand the experiences of the first group of students who entered the school when a project focused on developing strengths was put in place, with a targeted approach to students' talents. To highlight "strengths," curricular and pedagogical approaches were used, aligned with the students' cognitive styles, learning preferences and intelligence profiles. "Focus on talent" was sought as constant identification and recognition of the student's advanced skills and options to explore and express these skills and interests within and outside the curriculum. The "talent development" took place in support of talents and skills identified (Baum et al., 2014). The results indicated cognitive, emotional, and behavioral changes in social domains. The authors concluded that the teams working with children should be encouraged to consider them as a whole, through a positive approach, and direct students' attention to interests, strengths, and talents (Baum et al., 2014).

In the study by Proctor et al. (2011), the subjects of the intervention called "Strengths Gym Program", were 319 adolescents aged between 12 and 14 years. The objective was to develop character strengths and life satisfaction, justified by a connection to the well-being and prosperity among children and young people, reducing psychopathologies and externalized behavioral problems, as well as improving academic performance. Therefore, the intervention had three levels, according to the school year (years 7, 8 and 9) each student was handed a booklet entitled "Distinguish your strengths", defined as "your best qualities", and asked "what strengths do you think best describe you?" Students were asked to select five strengths from a list of 24 strong points from the Inventory of Strengths (Peterson \& Seligman, 2004). The authors observed a significant increase in adolescents' life satisfaction in those who participated in the intervention, supporting the hypothesis that the application of positive psychology theory in the school curriculum is relevant (Proctor et al., 2011).

The study by Shoshani and Steinmetz (2014) evaluated an intervention designed to improve the mental health of 537 students from seventh to ninth grade of an educational center in Israel. The intervention program lasted a year and was aimed at strengthening self-esteem, self-efficacy, and optimism. The subjects were divided into two groups. The intervention group participated in two parallel phases: (1) teachers participated in activities and training workshops with psychologists and (2) teachers administered a program to students in the classroom, including poems and stories, discussions, video clips, films and activities dealing with the subject of gratitude and positive experiences. The control group followed the regular curriculum. The authors noted that there were reductions in the scores of anxiety and depression symptoms, as well as a reduction of symptoms of interpersonal sensitivity in the intervention group.

The study by Leventhal et al. (2015) conducted a resilience based program for 2,308 girls living in a rural region in India, average age $12.99(\mathrm{SD}=1.17)$, students of 57 governmental schools. The program, called Girls First Resilience Curriculum (RC), was facilitated by women with 10th-grade education. The program focused on improving social-emotional strengths, psychological well-being, social well-being, and emotional resilience and was composed of 9 topics, totaling 23 sessions for the whole program. The themes of the topics, in order, were: (1) Setting group guidelines and listening skills; (2) Character strengths; (3) Goals, plans and life stories; (4) Emotional consciousness by identifying and expressing feelings; (5) Assertive communication, management of emotions and its benefits; (6) Restorative practices for solving conflicts and identifying opposing violence; (7) Problem solving focused on forgiveness, apologies, self-esteem and character strengths; (8) Developing a concept of peace with a "Peace Project" planned by the students; (9) Review, celebration and gratitude by written appreciations for one another. The results showed no effects on students with depression, but a small significant difference was found in students with anxiety - though the difference was not clinically significant. Otherwise, the study showed that the RC improved psychological strengths and well-being for girls in high-poverty rural schools.

The study by Tomyn (2015) addresses the "Subjective Wellbeing Homeostasis Theory", a sample of 4,243 participants in an Australian program for adolescents at risk. The Homeostasis Theory proposes that subjective well-being is maintained by automatic neurological control. The objective of the proposed program is to improve the subjects' education and employment opportunities, as well as to help them to make more positive life choices. The type of support depends on the situation of each subject, including career counseling, support with family issues, mental health and counseling services, education and employment. Group 
activities were also carried out to improve self-esteem, professional skills, literacy and motivation. It was observed that the program increases the subjective well-being of the subject.

Among university students, three studies were found. Bridges et al. (2012) described a methodology of intervention among psychology students enrolled in a course in Positive Psychology. Using a university blog platform as a marketing tool, the authors asked the students to complete three exercises, known as Three Good Things (at the end of each day for three weeks, remember three good things that happened); Strengths (using one of the main strengths in a new and different way every day for one week and leave a record of these activities on the blog) and the Gratitude letter (to write a letter of gratitude to someone who has been a positive influence). As a result of the course evaluation on a seven-point scale, which is required by the university, the students gave a significantly higher assessment of the Positive Psychology course that used the blog, both in the quality of the course and the teacher who administered classes, compared with the previous two semesters without the use of the blog (Bridges et al., 2012).

The following year, Place and Talen (2013) wrote an intervention among medical residency students seeking to develop resilience and well-being for the reduction of burnout and depression rates among them. The program is entitled Residency Wellness Program and has four main components: concrete resources, positive conversations, curriculum, and control. The authors report that education in positive psychology is effective against burnout and should be included in training programs, emphasizing the strengths, resilience, and protective factors among students (Place \& Talen, 2013).

Finally, contemplating the university context, the study by Duan et al. (2014) verified the effectiveness of an intervention in 285 Chinese graduate students, in order to increase their life satisfaction. For evaluation, we used the Action Inventory of Strengths (VIA-IS) in order to obtain the profile of each participant's personal strength of character. According to the authors, this is the first study of strengthbased intervention. The proposed intervention has been used together with the "Psychology Writing Skills Training" program, created as a complement. During the intervention, weeks 1 and 2 consisted of preparing for the intervention program, weeks 3-8 were intervention weeks, and weeks 9 and 18 consisted of retesting. During the intervention, subjects were divided into two groups, one called 'strength training' (intervention group) and the other control group. The activities were aimed at psychological writing skills and strategies for applying character strengths. On completion, all participants increased their satisfaction with life and happiness following the 18 -week intervention.

Regarding the studies that were addressed to teachers and school leaders, we have the research of Waters and Stokes (2015) and Aldenmyr (2012). Waters and Stokes, in a qualitative case study, described the effect of two interventions in the development of the positive attribute of gratitude. The sample consisted of 27 school leaders, aged between 25 and 60 , who worked in public and private schools in Australia. Of these, 55\% were women. The first intervention, which the authors called "gratitude journal" (exercise of three good things), asked the leaders to complete a diary for a week, reporting at the end of every three days things about their school for which they were grateful.

The second intervention, called "gratitude letter", invited the leaders to write a letter of gratitude to an important person in their lives, preferably a professional colleague or someone especially useful, inspiring, or kind to them in their leadership journey. The letter should be delivered and read to the person. As a result, the authors reported that the gratitude journal served to promote a balanced view of positive and negative events that occurred at school, to value relationships, and experience positive emotions, like hope, happiness, and optimism. However, it also triggered frustration at dealing with the paradox of having to look at things to feel grateful for, when this emphasizes problems.

The letter of gratitude resulted in a desire to invest in professional relationships, greater gratitude to people in leadership roles, and generated gratitude by staff and students (as reported by school leaders). On the downside, the gratitude letter generated feelings of vulnerability and concern for the possible discomfort that the letter could cause to the recipient. In addition, the results of this study demonstrate that while gratitude is largely a positive phenomenon, it can also trigger negative results and that it is the process of reconciliation between the positive and negative that allows for the emergence of a more engaged leadership form.

In the empirical and qualitative study by Aldenmyr (2012), entitled "Moral Aspects of Therapeutic Education", risks and potential possibilities were presented regarding the moral aspects of therapeutic approaches in education from the point of view of secondary school teachers. The discussion was based on Livskunskap, Life Competence Education (LCE), which seeks "socio-emotional training" in order to increase well-being, thereby preventing mental illness, drug abuse, crime, and other social problems. The program included five basic elements: self-awareness, control of feelings, empathy, motivation, and social skills. The author reports that all the teachers interviewed confirmed LCE as an expression of therapeutic education, which aims to develop self-esteem in students. The authors also discussed the student-teacher relationship, mentioning that it should be warm and close, in order to promote the intellectual and moral growth of the subjects, focusing on the work with self-esteem in education (Aldenmyr, 2012).

Despite the few studies found in this review, we observed that the area of Positive Psychology allied with education is comprehensive, including education at all levels. Regarding the education of school-age children, two of the nine 
interventions suggested were aimed at individuals with specific educational contexts, such as indigenous pupils (Rhodes \& Spiers, 2013) and children with high skills or learning disorders (Baum et al., 2014 ). Despite the diversity among the samples, interventions were generally related to emphasizing the strengths of the subjects, favoring an increase in well-being, and preventing social and behavioral problems (Aldenmyr, 2012).

Interventions differ, especially by their method of application, including games uniting parents and children outdoors (Niehues et al., 2013) or more systematic and specific training, such as that established by the study of Madden et al. (2011). The study by Baum et al. (2014) differs from other interventions, adding the term "talent" and focusing on support for previously identified skills. Among adult subjects, the activities included digital environments such as blogs, raising the level of complexity of the methodological resources used in the intervention (Bridges et al., 2012). It was also observed that with university students, the constructs used were expanded, including gratitude (Bridges et al., 2012) and resilience (Place \& Talen, 2013).

\section{CONCLUSION}

Given the results presented in this review, it was concluded that despite the growth in publications on Positive Psychology (Reppold, Gurgel, \& Schiavon, 2015), there are, as yet, few studies that aim to assess the effects of interventions based on this area directed towards Positive Education, as defined by Seligman (2009). Among the interventions described in this study, we realized the importance of stimulating the development of strength of character among students, and other specific constructs such as life satisfaction, gratitude, and resilience. This fact results in higher positive psychological attributes and positive cognitive, emotional, and behavioral changes, thus reflecting in social relationships among students themselves, teachers, and parents.

It should be noted that the studies found, for the most part, show no randomized controlled design, reducing the quality of the evidence found. These studies remained in the review since they provide the opportunity to discuss the current literature and existing gaps. Regarding the study's limitation, we can consider the use of a term not indexed for the search ("Positive Education"). However, it remains as the most suitable theoretically for the subject of this review. It is suggested, therefore, that more studies are conducted in order to evaluate the effectiveness of interventions in positive education in diverse settings, such as primary education and university for both young people and adults. In addition, more scientific publications are needed that seek to highlight the importance of motivating students towards a more attractive education, considering the fact that, as described by Baum et al. (2014), the subjects build happier lives through the development of strengths, not remediation of weaknesses. Therefore, it is concluded that Positive Education represents more than a movement derived from Positive Psychology and implies a theoretical and methodological approach and a policy of viewing human beings in a holistic/comprehensive manner, promoting an education that enables the development of their full potential and well-being.

\section{REFERENCES}

Aldenmyr, S. I. (2012). Moral aspects of therapeutic education: A case study of life competence education in Swedish education. Journal of Moral Education, 41(1), 23-37. doi: 10.1080/03057240.2011.638709

Baum, S. M., Schader, R. M., \& Hébert, T. P. (2014). Through a different lens reflecting on a strengths-based, talent-focused approach for twice-exceptional learners. Gifted Child Quarterly, 58(4), 311-327. doi: 10.1177/0016986214547632

Beck, J. S. (2005). Beck youth inventories. Second edition for children and adolescents manual. San Antonio, TX: Harcourt Assessment.

Beckley, D. (1998). Gifted and learning disabled: Twice exceptional students. Connecticut: University of Connecticut. Retrieved from https://nrcgt.uconn.edu/newsletters/sprin g984/\#

Bridges, K. R., Harnish, R. J., \& Sillman, D. (2012). Teaching undergraduate positive psychology: An active learning approach using student blogs. Psychology Learning and Teaching, 11(2), 218-227. doi: 10.2304/plat.2012.11.2.228

Christopher, J. C., Richardson, F. C., \& Slife, B. D. (2008). Thinking through positive psychology. Theory \& Psychology, 18(5), 555-561. doi: 10.1177/0959354308093395
Duan, W., Ho, S. M. Y., Tang, X., Li, T., \& Zhang, Y. (2014). Character strength-based intervention to promote satisfaction with life in the chinese university context. Journal of Happiness Studies, 15, 1347-1361. doi: 10.1007/s10902-013-9479-y

Green, S., Oades, L., \& Robinson, P. (2011). Positive education: Creating flourishing students, staff and schools. In R. Croswell (Ed.), InPsych (pp. 16-18). Melbourne: Australian Psychological Society. Retrieved from http://www.psychology. org.au/publications/ inpsych/2011/april/green/

Guyatt, G. H., Oxman, A. D., Vist, G. E., Kunz, R., Falck-Ytter, Y., Alonso-Coello, P., \& Hünemann, H. J. (2008). GRADE: An emerging consensus on rating quality of evidence and strength of recommendations. BMJ, 336 (7650), 924-926. doi: 10.1136/ bmj.39489.470347.AD.

Hart, K., \& Sasso, T. (2011). Mapping the contours of contemporary positive psychology. Canadian Psychology, 52, 82-92. doi: $10.1037 / \mathrm{a} 0023118$

Hutz, C. S. (2014). Avaliação em psicologia positiva. Porto Alegre, RS: Ed. Artmed.

Leventhal, K.S., Gillham, J., DeMaria, L., Andrew, G., Peabody, J., \& Leventhal, S. (2015). Building psychosocial assets and 
wellbeing among adolescent girls: A randomized controlled trial. Journal of Adolescence, 45, 284-295. doi: 10.1016/j. adolescence.2015.09.011

Madden, W., Green, S., \& Grant, A. M. (2011). A pilot study evaluating strengths-based coaching for primary school students: Enhancing engagement and hope. International Coaching Psychology Review, 6(1), 71-83.

Miles, M. B., \& Huberman, A. M. (1994). Qualitative data analysis (2nd Ed.). Newbury Park, C. A.: Sage.

Niehues, A. N., Bundy, A., Broom, A., Tranter, P., Ragen, J., \& Engelen, L. (2013). Everyday uncertainties: Reframing perceptions of risk in outdoor free play. Journal of Adventure Education and Outdoor Learning, 13(3), 223-237. doi: 10.1080/14729679.2013.798588

Oades, L. G., Robinson, P., Green, S., \& Spence, G. B. (2011). Towards a positive university. The Journal of Positive Psychology, 6(6), 432-439. doi: 10.1080/17439760.2011.634828

Peterson, C., \& Seligman, M. E. P. (2004). Character strengths and virtues: A classification and handbook. Washington, DC: American Psychological Association.

Place, S., \& Talen, M. (2013). Creating a culture of wellness: Conversations, curriculum, concrete resources, and control. International Journal of Psychiatry in Medicine, 45(4), 333344.

Positive Education Schools Association. (n. d.). Retrieved from http://www.pesa.edu.au

Proctor, C., Tsukayama, E., Wood, A. M., Maltby, J., Eades, J. F., \& Linley, P. A. (2011). Strengths gym: The impact of a character strengths-based intervention on the life satisfaction and well-being of adolescents. Journal of Positive Psychology, 6(5), 377-388.

Reppold, C. T., Gurgel, L. G., \& Schiavon, C. C. (2015). Research in positive psychology: A systematic literature review. PsicoUSF, 20(2), 275-285. doi: 10.1590/1413-82712015200208

Rhodes, D. B., \& Spiers, H. (2013). Creating educational equity for indigenous students through significant organisational change. International Journal of Educational Organization and Leadership, 19(4), 27-37.
Seligman, M. E. (2002). Authentic happiness: Using the new positive psychology to realize your potential for lasting fulfillment. New York: Simon and Schuster.

Seligman, M. E. (2011). Florescer. Rio de Janeiro: Editora Objetiva. Seligman, M. E., Ernst, R. M., Gillham, J., Reivich, K., \& Linkins, M. (2009). Positive education: Positive psychology and classroom interventions. Oxford Review of Education, 35(3), 293-311. doi: 10.1080/03054980902934563

Seligman, M. P., \& Csikszentmihalyi, M. (2000). Positive Psychology: An introduction. American Psychologist, 55(1), 5-14.

Shoshani, A., \& Steinmetz, S. (2014). Positive psychology at school: A school-base intervention to promote adolescents' mental health and well-being. Journal of Happiness Studies, $15,1289-1311$.

Sin, N., \& Lyubomirsky, S. (2009). Enhancing well-being and alleviating depressive symptoms with positive psychology interventions: A practice-friendly meta-analysis. Journal of Clinical Psychology: In Session, 65, 467-487. doi: 10.1002/ jclp.20593.

Snyder, C. R., \& Lopez, S. J. (2009). Psicologia positiva: Uma abordagem cientifica e prática das qualidades humanas. Porto Alegre, RS: Ed. Artmed.

Tomyn, A. J., Weinberg, M. K., \& Cummins, R. A. (2015). Intervention efficacy among 'at risk' adolescents: a test of subjective wellbeing homeostasis theory. Social Indicators Research, 120, 883-895.

Waters, L. (2011). A review of school-based positive psychology interventions.The Australian Educational and Developmental Psychologist, 28(02), 75-90. doi: 10.1375/aedp.28.2.75

Waters, L. (2015). Stokes, H. Positive education for school leaders: Exploring the effects of emotion-gratitude and action-gratitude. The Australian Educational and Developmental Psychologist, 32(1), 1-22.doi: 10.1017/edp.2015.1

White, M. A., \& Waters, L. E. (2015). A case study of 'The Good School:' Examples of the use of Peterson's strengths-based approach with students. Journal of Positive Psychology, 10(1), 69-76.doi: 10.1080/17439760.2014.920408 